\title{
2 Linguistic Mysteries Around the North Sea
}

Östen Dahl

Stockholm University

Everyone who knows anything about the history of the Germanic languages knows that English was influenced by Scandinavian around the Viking Age. The question I will raise in this paper, without giving any definite answer, is: Did the contacts across the North Sea have any effect on the Scandinavian languages? As far back as ten years ago, Maria Koptjevskaja Tamm and I asked the same question in a conference presentation that never resulted in a published paper (but see Dahl 20I0a, 20Iob for some discussion). Our point of departure was the striking similarities between the possessive constructions called "s-genitives' in English and the Scandinavian languages, and the observation that in Scandinavia, $s$-genitives are by and large found only in standard Danish, standard Swedish, and some Danish-influenced varieties of Norwegian. Moreover, it seemed that the origin of $s$-genitives was in western Denmark, next to the North Sea.

In this connection, two papers by the Danish Scandinavianist Kristian Ringgaard seemed relevant (Ringgaard 1986, I989). Ringgaard argues against the common view that the simplification processes that took place in the Danish inflectional system in the Middle Ages were due to the intensive contacts with Low German in the Hanseatic period. Referring to earlier work by Anders Bjerrum, he argues that these processes started much too early to be triggered by the influx of German merchants, whose culmen was in the second half of the I 4 th century. He also argues that there were significant differences within the Danishspeaking area as to the strength and chronology of these processes, with a cline Jutland>Island Danish $>$ Scanian. In the second paper, Ringgaard focuses on Jyske Lov 'The Jutlandic Law', one of the provincial Danish laws, signed by King Valdemar II in I24I. Ringgaard's textual source is

How to cite this book chapter:

Dahl, Ö. 20I 5. Linguistic Mysteries Around the North Sea. In: Shaw, P., Erman, B., Melchers, G. and Sundkvist, P. (eds) From Clerks to Corpora: essays on the English language yesterday and today. Pp. I7-34. Stockholm: Stockholm University Press. DOI: http://dx.doi.org/Io.I6993/bab.b License: CC-BY. 
the Flensburg manuscript, which was at the time considered the oldest version, dated to I300; later, another manuscript, Codex Holmiensis, has been reliably dated to I27I. Ringgaard describes the language in Jyske Lov as having among other things the following features - all innovations relative to the language found in Runic inscriptions:

two genders for nouns (residual feminine gender)

no nominative-accusative distinction

generalized $s$-genitive

dative only in lexicalized expressions

definite articles are rare and always postposed

no case inflections in adjectives

participles tend to lack a neuter form

examples of singular verb forms with plural subjects occur

No exact date for when the law was formulated can be given; Ringgaard notes that the version that existed in $\mathrm{I} 24 \mathrm{I}$ would have been written by people born around I200, even if they may have relied on earlier legal rules. He notes that modern dialects in western Jutland show features that mark it off as a "radical innovation area". What we see then is that a language with a surprisingly "modern" grammar must have been spoken somewhere in western Denmark well before Hanseatic contacts could have had an effect on the language.

Ringgaard is himself slightly baffled by his findings; he wonders why innovations would spread from western Jutland, which was not the centre of the realm in historical times, and speculates that in fact the changes started much earlier, perhaps as early as the period I00-500 CE. But perhaps part of the explanation could rather be found on the other side of the North Sea.

The story of the Scandinavian presence in Britain has been told many times, but much of what really happened is still in dispute. Viking raids began already in the 8th century; they were undoubtedly spectacular but had hardly any bearing on linguistic developments. Towards the end of the 9th century, more ambitious attempts of military takeover began, and in 886 the Danes and the kingdom of Wessex made an accord in which the Danes were given control over a large part of northern and eastern England (the "Danelaw"). During the period that followed, there was considerable migration from Scandinavia to the Danelaw areas, the extent and nature of which have been much debated, as we shall see later. What is not being questioned, however, is 
that the Scandinavian settlements in the Danelaw were the basis for the impact that Scandinavian languages have had on English. Around the middle of the Ioth century, the Danes had lost their political control of the Danelaw, and the Scandinavian parts of the population were presumably being integrated with the Anglo-Saxon elements, although it is not possible to judge how fast this process was.

Towards the end of the century, the Danes renewed their attacks on England, as a result of which the English were forced to pay large tributes ("Danegeld"). On November I3, IOO2 ("St. Brice's Day"), the English king Æthelred "the Unready", in his own words, sent out a decree "to the effect that all the Danes who had sprung up in this island, sprouting like cockle amongst the wheat, were to be destroyed by a most just extermination" (as translated in Whitelock I996: 545). From the modern point of view, this seems like a surprisingly candid admission of ethnic cleansing. It is unlikely that it was directed against the population of the Danelaw; rather, it concerned recently arrived Danes, but it indicates that they must have been present in significant numbers. Æthelred did not attain the goal of ridding England of Danes; on the contrary, after a decade of continued raiding, the Danish king Sweyn Forkbeard managed to secure the English throne in IOI3, but died shortly thereafter. After three years of political unrest, his son Cnut became King of England and ruled it together with Denmark and Norway until his death in 1035, when he was succeeded by his son Harthacnut whose death in 1042 marked the end of Danish rule in Britain. The epilogue came 25 years later, after the Norman invasion, with "the Harrying of the North", another campaign, the character and extent of which are controversial, but which is claimed by contemporary sources to have laid large parts of the Danelaw waste, with possibly as many as a hundred thousand people killed.

Turning now to the main issue of the paper, the first observation to be made here is that there is a similarity between the histories of English and East Nordic (Danish and Swedish) in that there is a hiatus in the beginning of the second millennium $\mathrm{CE}$, during which there is very little written documentation of the languages. Furthermore, when the languages started being used in writing after the hiatus, they seem to have undergone, or started to undergo, quite similar simplifications in their morphology. It is also during and around this period that contacts across the North Sea are at their peak.

The extent to which Scandinavian was spoken in England, as well as its impact on English, has been much disputed. To start with, there are 
different views on the length of the migration period. Thomason and Kaufman (I988: 267) say that "Norse speakers settled in the North and East of England during the period from 865 to 955 (though not in the East after 920)". Baugh and Cable (I993: 96), quoted approvingly by Emonds and Faarlund (ms.), say that " $[\mathrm{u}] \mathrm{p}$ until the time of the Norman Conquest the Scandinavian language in England was constantly being renewed by the steady stream of trade and conquest..." and consequently, "many of the newcomers ... continued to speak their language at least as late as I го०”. Emonds and Faarlund agree that "we can say with some certainty that at the outset of Norman rule, the Danelaw contained many speakers of two distinguishable languages, one of them being Norse". Thomason and Kaufman (I988: 288), on the other hand, think that Norse had disappeared from large parts of the Danelaw before the end of the first millennium although it was spoken in present-day Yorkshire until about IOI 5. Similarly, they say (I988: 302) that the influence of Norse on English "was pervasive, in the sense that its results are found in all parts of the language; but it was not deep, except in the lexicon". For Emonds and Faarlund (ms.), on the other hand, "influence" is the wrong word, since Old Norse is in their view the mother language of Middle and Modern English.

For the understanding of what happened to English and the North Germanic languages during and around the Viking age, it is important to keep apart two major types of contact-induced change: one is transfer of features, leading to increased similarity between languages; the other is simplification due to imperfect learning by second-language speakers. The latter type is of particular interest since both English and Mainland Scandinavian underwent quite significant simplification processes in their morphology. As noted above, the breakdown of the old inflectional system in Mainland Scandinavian has been attributed to contact with Low German, but Ringgaard argued that this would be the wrong time and the wrong place. For English, three possible culprits have been proposed: Norman French, Celtic, and Old Norse. Trudgill (20I0) invokes what he calls "sociolinguistic typology" and the suggestion that the structure of a language may be at least partly determined by the type of social environment and social structure in which it is spoken. Thus, he claims, long-term contact situations influencing child language acquisition will tend to lead to complexification through the addition of features from other languages, whereas short-term contact involving adult language learning tends to lead to simplification, due to the problems adults have in coping with irregularity and nontransparency. 
Norman French, like Low German in the Scandinavian case, can be acquitted since it would be the wrong time - the changes begin earlier and the wrong place - the changes start in the north, where there were few Normans. As for the choice between Celtic and Old Norse, several scholars have recently suggested that Brittonic Celtic may have survived much longer than was earlier thought (Tristram 2002, 2004; Schrijver 2006; Laker 2008; Trudgill 2010). Furthermore, the sociolinguistic situation makes simplification much more probable in the case of the contact between the Anglo-Saxons and the Celts than in the contact between the Anglo-Saxons and the Vikings. In the former case, a large population submitted to a relatively small group of intruders; in the latter case, the situation would be the reverse. Tristram (2004) hypothesizes that there was a long period of diglossia, in which the majority of the population spoke "Brittonic English" and only the aristocracy the "purer" variety of Old English. The variety that the Norse immigrants mainly met could well be Brittonic English, in which categories such as gender and case would already have disappeared due to imperfect learning. The role of the contact with Norse would then be at most to strengthen the processes that had already been initiated earlier.

Against this background, let us now consider what happened at roughly the same time or a bit later in Scandinavia. As already noted, many linguistic changes in the Middle Ages seem to have originated in western Denmark (Jutland) and progressed east. In fact, some of them continued beyond what was then considered as Denmark (that is, including the southernmost Swedish provinces). However, as we get further away from the point of origin, changes tend to be later and weaker. The regions in Mainland Scandinavia that show most resistance are Norway, northern Sweden and the trans-Baltic areas. Island Scandinavian (Icelandic and Faroese) were often not reached at all. The striking observation is now that in a number of cases, these developments have close parallels in Britain. Let us look at the most important of them.

\section{Reduction of unstressed vowels and apocope}

This is a type of phonological change that took place in large parts of the Germanic-speaking area and also has parallels in some Romance languages. It has been blamed on earlier prosodic changes (initial wordstress) and has also been used to explain the general simplification of the inflectional systems in West European languages. There are basically 
two possible outcomes of this process: (I) unstressed vowels (particularly final ones) are reduced to $e$ or schwa; (2) these vowels disappear altogether (apocope or "schwa loss"). During the Middle Ages, the first possibility was realized generally in West Germanic and in western and central Danish - but only to a limited extent in Peninsular Scandinavian; the second outcome is found in a smaller area, according to Thomason and Kaufman (1988: 319): "English, Dutch, some Frisian, some Low German, and some High German". Crucially to our discussion, "some Danish" should be added to this list, more specifically West Jutlandic. In English, the reduction process started already in the OE period. The apocope started in the north and was already spreading to the south in the period I I00-I250 (Minkova I99I: 30). According to Perridon (2005: I023), all unstressed final vowels were reduced to $\alpha$ or $e$ in western and central Danish as early as "in the I 2 th century, or even earlier". Loss of final vowels is attested in early manuscripts such as Jyske lov - that is, more or less simultaneously with the spread to southern England - and has been generalized in modern Jutlandic dialects. The timing of the process in Danish would allow for influence from the south for the vowel reduction but hardly for the apocope, which seems to have taken place later in the neighbouring languages, to the extent that it took place at all (Ringgaard I986: I 82).

\section{The case system}

As noted above, the breakdown of the old noun case system had already gone quite far in the language of $\mathrm{I}_{3}$ th century western Denmark as represented in Jyske Lov. The distinction between nominative and accusative had disappeared almost wholly, with some remnants in adjectives, and the dative was used almost exclusively in lexicalized prepositional phrases (Bjerrum I966: 58). (The genitive will be discussed below.) In Peninsular Scandinavian, the process was much later, and has not yet been brought to completion in some dialects in the north.

Looking at Middle English, we find that the situation in Jyske Lov comes very close to the way the mid-I 2 th century text in the Peterborough chronicles is presented in Burrow \& Turville-Petre (I99I: 29), where the nominative and accusative have no endings, and the dative in - $e$ of strong nouns is said to sometimes occur after prepositions, "but is as often uninflected" and "...in later texts the inflexion is dropped altogether except in a few phrases". Likewise, case inflections in adjectives were preserved only in the South "to a limited extent". 
It is interesting to contrast this with the Old Danish letter from late I4th century Halland (then part of Denmark, now a province of Sweden) quoted in Ringgaard (I986: I8I), where "there is not much to object to the inflectional system", that is, the old system is more or less fully preserved - as it also was in Middle Low German (a distinction nominative-oblique is still alive in present-day Low German). In other words, I 3 th century western Danish aligns more closely with I2th century Midland English than with I4th century eastern Danish and with its neighbours to the south.

\section{The genitive}

In many Germanic languages, the genitive case has undergone developments that set it off from the rest of the case paradigm. Thus, one single case suffix, $-(e) s$, which originally marked the genitive singular of non-feminine nouns, has survived even in the languages where the case system has otherwise broken down but is used in innovative possessive constructions and has been generalized to feminine and sometimes plural nouns. As noted above, the $s$-genitives of English, Danish and Swedish share a number of properties, in particular: a uniform suffixed marker $-s$ which (i) can be used with all types of noun phrases; (ii) is added to the last word of the possessor NP (rather than to the head noun); (iii) always precedes the head noun of the possessee NP; (iv) is used with a possessee NP which lacks definiteness marking. Properties (i-ii) make these $s$-genitives different from similar constructions in West Germanic, which tend to be restricted to proper and kinship nouns and mostly do not appear in complex NPs. Properties (iii-iv) distinguish them from constructions found in some Swedish traditional dialects, where the possessee NP takes a definite suffix and the genitive phrase may follow the head noun of the possessee NP. It should be noted that $s$-genitives are virtually non-existent in the traditional dialects of Northern Scandinavia, where a plethora of other possessive constructions are used instead (Delsing 2003; Dahl 2010a).

Ringgaard's statement about Jyske Lov, "the s-genitive was generalized", has to be modified - it was rather "generalizing". Perridon (2013) made a thorough investigation of a number of manuscripts and found a rather complex pattern of variation. In particular, the genitive is sometimes zero-marked, as in sankte knut sun 'St. Cnut's son'. In definite nouns, forms such as landoens 'the land's' competed with forms with double genitive marking like landzoens. In a later development, a 
"linking pronoun construction" - parallel to the much debated English type John his house - gained ground in western Denmark and is preserved in modern Jutlandic, while the s-genitive was further generalized in more eastern varieties.

Middle English is usually said to have a single genitive ending -es but zero marking is also found. A particularly striking attestation is found on the Kirkdale sundial, dated to I060, which contains the phrases in Eadward dagum 'in Edward's days' and [i]n Tosti dagum 'in Tosti's days'. Thomason and Kaufman (I988: 289) note that this is one trait found in the sundial text that characterizes Northern Middle English although "the writers of the text were evidently trying to write Standard West Saxon". Klemola (I997) argues on the basis of modern dialect data and quotations from earlier scholars that there was a loss (apparently general) of the genitive endings in a northern area including Yorkshire. Zero marked genitives are one of the traits that are mentioned as characteristic of Yorkshire speech. As the s-genitive has been generalized in Standard English, this means that the similarities across the North Sea are today greater in the standard languages than in the dialects in the areas where the original contact took place. As for the development of the $-s$ marker from an affix to a clitic (or "phrasal affix") in English and Scandinavian, it is hard to say if they have a common origin, since unequivocal attestations of "group genitives", that is, $s$-genitives marked on the last word of the NP rather than on the head noun, are relatively late. Allen (2008: I 53) provides an example from I 387 of an $-s$ attached to a postmodifier: pe kyng of Fraunces men. Perridon (2OI3: I42) cites as the first comparable example from Danish pana hans allar rigens aff Danmarks wegna 'on behalf of him or the kingdom of Denmark' from I4 IO.

Summing up, the story of the s-genitive is a complex one: on both sides of the North Sea we see a competition between generalized s-genitives, zero-marked genitives and linking pronoun constructions, but and even if the parallels are striking, it is not possible to construct a coherent narrative that would show how the developments are linked together.

\section{Gender}

In standard Danish and Swedish and conservative Bokmål Norwegian the original Germanic three-gender system - which is still preserved in most non-standard varieties in Peninsular Scandinavian and even in some Danish traditional dialects - has been reduced to a distinction between 
common and neuter gender. In general, these varieties use the erstwhile demonstrative den to refer to non-neuter inanimates. According to Ringgaard, (1989: I63), the two-gender system is found already in Jyske Lov, meaning that the simplification process must have started no later than the $3_{3}$ th century and probably earlier. In large parts of Jutland, the common:neuter distinction has also been abolished or (mainly for pronominal reference) been transformed into a semantically-based count: mass distinction. Even this more radical state-of-affairs may be reflected in the earliest texts to some extent (Perridon 2005: IO2I).

The three-gender system was more or less intact in Old English but had already gone in the earliest texts in Early Northern Middle English and was also on its way out in other varieties of Early Middle English. In the choice of pronouns, however, there was a certain tendency towards "natural gender" already in Old English (Curzan 2003).

Gender, especially of the "non-natural" type not motivated directly by semantics, is often thought of as a quirk that languages will tend to get rid of as soon as possible. However, gender systems are astonishingly stable overall. (For a more detailed discussion, see Dahl (2004: 196-202), and for a survey of earlier views on gender, see Kilarski (2007)). Only a small number of Indo-European languages have lost their gender systems altogether - outside Germanic it has happened in some Iranian languages and Armenian. According to McWhorter (2002: 230), the loss of NP-internal gender in English makes it unique "among all the languages of Europe" except for "a few nonstandard dialects of particular languages". He mentions two non-Germanic examples, both said to be due to language contact, and two Germanic ones, "Western Danish" and "Ostrobothnian Swedish" - which he labels as "cases of internal loss". The references to the varieties in question are not quite exact - "Western Danish" is the area in Jutland referred to above, and "Ostrobothnian Swedish" is not all of the Swedish speaking area of Ostrobothnia but only the northernmost part of the Swedish speaking area of Finland. Given the proximity to Finnish, a genderless language, an account in terms of language contact would seem natural here too, which leaves English and Jutlandic as the only cases to be explained which makes one wonder if they are really independent of each other.

\section{"Direction of case levelling"}

As an argument for their position that English is a North Germanic language, Emonds and Faarlund (ms.) mention that both English and 
Danish/Norwegian (but not Swedish) share the tendency to use the object forms of pronouns in all positions other than uncoordinated subjects of overt finite verbs, as in It's me or Danish Det er mig. Prima facie it looks as if English could have been influenced by French on this point, since in French the pronouns used in those positions are derived from Latin accusative forms. However, French makes a distinction that English lacks, namely between the clitic pronouns used with uncoordinated direct objects, e.g. me 'me' or te 'you', and the "full' pronouns used e.g. in C'est moi 'It's me'. Basing themselves on this difference, Emonds and Faarlund (ms.) reject the possibility of French influence.

Timing is critical here. Emonds and Faarlund's formulation "some kind of extension of either subject or object forms took place in all Germanic languages in which case distinctions are restricted to pronouns" suggests that they assume a connection between the loss of case distinctions on nouns and the extension of subject or object forms. But this seems to imply that either (i) the nominative-accusative distinction had already disappeared in the last common ancestor of English and Scandinavian or (ii) the similarity is due to later contact between Scandinavia and England. In fact, Emonds and Faarlund say that they do not exclude this possibility even if their preferred hypothesis seems to be that "ME pronominal case patterns simply continued those of Old Danish". But if the change is due to contact, there is not really any reason why it could not equally well go from west to east.

\section{The definite article}

Most Scandinavian varieties have one postposed and one suffixed definite article whose distribution varies according to slightly complex patterns (Dahl, 2003). West and South Jutlandic varieties also have two definite articles, with basically the same distribution as the standard Danish ones, but the one that corresponds to the suffixed article, that is, the one that is used when there is no modifier before the head noun - is an invariable marker $\propto$ which always precedes the noun, as in $\propto$ by 'the town'. This has been claimed to be due to influence from Low German. Perridon (2005: IOI9) argues that the isomorphism between the Danish and the Jutlandic systems speaks against this. He also argues against the possibility that the Jutlandic dialects have replaced an earlier suffixed article by a prefixed one, and hypothesizes that Jutlandic $\infty$ and the definite suffix arose at the same time, in the I Ith or I 2 th century, in spite of the fact that $\propto$ is only attested from the I 6 th century onwards. 
He attributes the difference in position to the timing of the change from postposition to preposition attribute-noun order, which was earlier in South and West Jutland. Yet, if Perridon is right about the time of the change, it coincides with the period when influence from English could be expected. Furthermore, the Jutlandic and the English articles share a feature not found elsewhere in Germanic languages at this time - they are invariable, not only in gender and case but also in number. The invariable article $p e$ is another of the innovations in Middle English that were established early in the North and then spread to the south. White (2002) and Tristram (2004) invoke influence from Brittonic Celtic, where there was also an invariable definite article which, as they argue, was older than the English one.

\section{Verb morphology}

In the present indicative, Old English distinguished all persons in the singular and none in the plural. By contrast, Old Norse distinguished all persons in both the singular and the plural except for the second and third singular. Both Northern Middle English and Old Danish had virtually the same simplified system in which there were no person distinctions except that the first person singular was optionally different from the second and third persons (although there seems to have been a difference in the extent to which this distinction was made).

It thus seems that the systems have converged in that distinctions that were not made in both Old English and Old Norse were abandoned. However, this convergence was at least initially restricted to NME and Old Danish; other varieties of Middle English and Medieval

Table 1. Verb endings in Old English, Northern Middle English, Old Danish, and Old Norse.

\begin{tabular}{|c|c|c|c|c|}
\hline & $\mathrm{OE}$ & NME & Old Danish & $\mathrm{ON}$ \\
\hline Isg & $-e$ & -e/-es & -e/-er & $-a$ \\
\hline $2 s g$ & -est & -es & -er & $-a r$ \\
\hline $3 \mathrm{sg}$ & $-\mathrm{ep}$ & -es & -er & -ar \\
\hline Ipl & $-a p$ & $-e$ & $-e$ & -um \\
\hline $2 \mathrm{pl}$ & $-a p$ & $-e$ & $-e$ & -ið \\
\hline $3 \mathrm{pl}$ & $-a p$ & $-e$ & $-e$ & $-a$ \\
\hline
\end{tabular}


Scandinavian kept the old systems to a much larger extent. The system of Modern Icelandic is identical to that of Old Norse and in Swedish, three persons were distinguished in the plural at least in the written language for many centuries, and Elfdalian still keeps this system.

\section{Possessive reflexives}

Older forms of Germanic made a distinction in the third person between (i) the reflexive pronoun $\sin$ which agreed with its head noun and (ii) the non-reflexive, non-agreeing genitive pronouns. In the modern languages, this distinction is retained only in North Germanic. In West Germanic, two different developments have taken place, both leading to the disappearance of the distinction. In Continental West Germanic, the process seems to have been one of fusion between the two types of pronouns, resulting in a generalization of the agreeing type. In English, on the other hand, the non-reflexive forms were generalized and the reflexive pronoun disappeared without trace already in the course of the Old English period.

As an exception to the general retention of the reflexive possessive in North Germanic, Danish uses the possessive reflexive sin only in the singular, and in West and South Jutlandic the distinction between reflexive and non-reflexive pronouns has generally been lost; sin is retained as a general non-human possessive, for human referents the ordinary, non-agreeing possessive pronouns are used. Perridon (I999: I 85 ) rejects the possibility of Low German influence, as Low German does not have non-agreeing possessives. I am not sure how strong this objection is, but it can be noted that it could not be used against the alternative hypothesis that we are dealing with influence from English, where, as mentioned above, the non-agreeing pronouns were generalized.

\section{Other phenomena}

There are a few other points where there is a split between Danish and some or all Peninsular Scandinavian varieties, and the Danish pattern is also found in English, but where I have not found sufficient information about the historical development. These will just be briefly mentioned here with Swedish as representing the other side of the split:

- In presentational sentences ('There is beer in the fridge'), Swedish uses a neuter pronoun (det) as an expletive but English and Danish use an original adverb (there and der respectively); 
- In Swedish, pronominal objects normally follow a verb particle, in English and Danish they normally precede it;

- In Danish possessive pronouns consistently precede the head noun; in Swedish they optionally follow kin terms, and in many Swedish and Norwegian varieties postposed possessives are the norm.

Thus, we have seen that the grammatical changes that have shaped the modern standard Scandinavian languages, in particular standard Danish and Swedish, largely originated in western Denmark, and that many of them have been more strongly implemented in Denmark, especially the western parts. We have also seen that a significant part of the changes had already made their way into Old Danish as it was written in western Denmark in the mid or late I 3 th century. Furthermore, many of them closely parallel what happened in the transition from Old English to Middle English, while resemblances to Continental West Germanic are considerably weaker, and parallel changes in those languages are often later.

These observations fairly strongly suggest that Old Danish, and later on and more indirectly, other Scandinavian varieties were influenced by English or Anglicized Norse, or both, during the transition period from Old to Middle English. There are some major stumbling blocks here, though.

One is that the influence appears to be essentially restricted to grammar and phonology. There are a number of words in the Scandinavian languages that are usually regarded as loans from Old or Middle English (although usually originally from Latin or Greek), but they tend to be connected with religion (such as Swedish ängel 'angel' and kyrka 'church') and are assumed to have arrived with Anglo-Saxon missionaries. It should be added that the number may be a bit larger than is usually thought, since it is not always possible to see which West Germanic language a word comes from, and there may be a tradition to routinely ascribe a continental origin to such cases. Quak (2005: 569) notes a number of presumed loans from Old Frisian which could equally well be from Old English. However, the absence of a larger number of clear loanwords from Old or Middle English in Scandinavian can be seen as a serious problem for the hypothesis that Scandinavian was under influence from the British Isles, especially if we assume that England was the culturally and economically more advanced part. (Compare the large number of Low German loanwords in Scandinavian and French loanwords in English.) 
The second stumbling block is how to find a credible account of how the influence took place. The result of the changes that have been discussed here was a major restructuring of the grammar of the Scandinavian languages, in particular of the inflectional system. An explanation in terms of contact-induced change demands that the contacts were more than superficial. We know that there were intimate contacts between Scandinavian and English in Britain, even if the intensity and length of the contact is controversial. It is a common assumption that this led to a mutual convergence of the languages, possibly including morphological simplification due to imperfect learning. For instance, Braunmüller (2005: 1033) speaks of a "transition from focused bidialectalism to the use of diffuse, jargon-like interdialectal variants in the next generation(s)". Thomason and Kaufman (I988) think that "there must have been heavy borrowing between the two languages before the Norse speakers in the end switched to English" and that "[if] the Norse had survived we would have seen a Norse equally riddled with English traits". But maybe the Norse survived after all, in some sense. If Danelaw Scandinavian was still around when the Danes took control of England after the millennium shift, it might have been strong enough to become some kind of prestige dialect in Cnut's empire, including Denmark.

Not much seems to have been said about language at Cnut's court. However, Frank (I994: I08) says in her paper on the poetry of the Scandinavian "skalds" there that there was a "casual use in the verse of Old English words, idioms, and syntax", as if

the skalds were composing for a Norse-speaking community enisled in a sea of Anglophones; at times the language seems almost AngloDanish, a dialect as distinct from Old Norse as Québecois is from metropolitan French.

She bases this statement on Hofmann (I955), one of the very few works that look seriously at the possible influence of English on Viking Age Scandinavian. Hofmann analyzed a number of poems by Norse "skalds" and indeed finds quite a few Anglicisms in them; it has to be admitted, however, that as examples of code-mixing they are not so impressive in comparison to what has been documented in the rich literature on such phenomena (see e.g. Muyskens 2000). Still, Frank's picture does not sound too unrealistic. In the enumeration of Cnut's earls in Keynes (I994) we find I2 Scandinavian earls and 9 English ones, giving the impression of a relatively even distribution of 
both groups in the ruling élite. There would have been a considerable linguistic diversity in these circles. On the other hand, the period of Danish control was probably too short for the linguistic situation to stabilize.

It is clear that being part of Cnut's empire also had an impact on Denmark. Two areas where Cnut had clear ambitions are often mentioned in the literature: religion and coinage (Lund I994; Jonsson I994). There were mints in all major regions of Denmark during Cnut's reign, and the Anglo-Saxon influence on the Danish church "was also more than traceable, it was massive" (Lund I994: 39). Already Cnut's predecessor Sweyn Forkbeard replaced the German bishops with English and Norwegian ones, and Cnut continued this policy. What this means from a linguistic point of view is that there will have been significant numbers of speakers of various forms of English and/or "AngloDanish" in Denmark - although it may be questioned how much this would influence the language spoken in Denmark in general.

One important but obscure point is to what extent there was remigration of Scandinavians from England. It seems likely that part of the Danes in England, particularly those who had arrived recently, would move back to Denmark when the Danes lost the political control. It may also be speculated that the harsh treatment of the population in the north after the Norman invasion may have driven some of them to seek refuge on the other side of the North Sea.

The ruling élite seems to have been quite mobile during this period. Among royals, marriages across ethnic and linguistic borders seem to have been the rule rather than exceptions, although this may of course have been less pronounced further down in the hierarchy. Cnut himself may have had a Slavic mother and possibly a Slavic paternal grandmother; his wives Ælfgifu and Emma were Anglo-Saxon and Norman, respectively. His nephew Sweyn Estridson, who was King of Denmark between 1047 and 1074, had a Norwegian father and was born in England; he married two Swedish women and one Norwegian woman.

All this may still seem a bit thin as a basis for the assumption that Old Danish was shaped in a decisive fashion by contacts across the North Sea. On the other hand, the alternative hypothesis is that the similarities we see between Early Middle English and Old Danish are due to parallel but independent developments - and that it is a pure coincidence that these parallels are strongest between the Danelaw area and western Jutland. For the time being, I think the linguistic mysteries around the North Sea will remain. 


\section{References}

Allen, C.L. (2008). Genitives in Early English: Typology and Evidence: Oxford/ New York: Oxford University Press.

Baugh, A.C. \& Cable, T. (I993). A History of the English Language. London: Routledge.

Bjerrum, A. (I966). Grammatik over Skanske lov: efter B 74. Copenhagen: Københavns Univ. Fond til Tilverjebringelse af Læremidler.

Braunmüller, K. (2005). Language contact during the Old Nordic period I: with the British Isles, Frisia and the Hanseatic League. O. Bandle, L. Elmevik \& G. Widmark (eds) The Nordic Languages: An International Handbook of the History of the North Germanic Languages (Vol. I). Berlin: Mouton de Gruyter, I028-1039.

Burrow, J.A. \& Turville-Petre, T. (I99I). A Book of Middle English. Oxford: Blackwell.

Curzan, A. (2003). Gender Shifts in the History of English. Cambridge: Cambridge University Press.

Dahl, Ö. (2003). Competing definite articles in Scandinavian. B. Kortmann (ed.) Dialectology Meets Typology. Berlin: Mouton de Gruyter, I47-I80.

- (2004). The Growth and Maintenance of Linguistic Complexity. Amsterdam: Benjamins.

- (20I0a). Grammaticalization in the North: Noun Phrase Morphosyntax in Scandinavian Vernaculars. Stockholm: Department of Linguistics, Stockholm University.

- Review of C. Allen: Genitives in early English: Typology and evidence. Diachronica 27:3, 489-496.

Delsing, L.-O. (2003). Syntaktisk variation i nordiska nominalfraser. L.-O. Delsing, Ø.A. Vangsnes \& A. Holmberg (eds) Dialektsyntaktiska studier av den nordiska nominalfrasen. Oslo: Novus.

Emonds, J. \& Faarlund, J.T. (ms.). English as North Germanic.

Frank, R. (I994). King Cnut in the verse of his skalds. A.R. Rumble (ed.) The Reign of Cnut, King of England, Denmark and Norway. London: Leicester University Press, I06-I 24.

Hofmann, D. (I955). Nordisch-englische Lehnbeziehungen der Wikingerzeit. Copenhagen: Munksgaard.

Jonsson, K. (1994). The coinage of Cnut. A.R. Rumble (ed.) The Reign of Cnut: King of England, Denmark and Norway. London: Leicester University Press, I93-230. 
Keynes, S. (1994). Cnut's Earls. A.R. Rumble (ed.) The Reign of Cnut: King of England, Denmark and Norway. London: Leicester University Press, 43-88.

Kilarski, M. (2007). On grammatical gender as an arbitrary and redundant category. D.A. Kibbee (ed.) History of Linguistics 2005: Selected papers from the Tenth International Conference on the History of the Language Sciences (ICHOLS X), I-5 September 2005, Urbana-Champaign, Illinois. Amsterdam: Benjamins, 24-36.

Klemola, J. ( I 997). Dialect evidence for the loss of genitive inflection in English. English Language and Linguistics I:2, 349-353.

Laker, S. (2008). Changing views about Anglo-Saxons and Britons. H. Aertsen \& B. Veldhoen (eds) Six Papers from the 28 th Symposium on Medieval Studies. Leiden: Leiden University Press, I-38.

Lund, N. (1994). Cnut's Danish kingdom. A.R. Rumble (ed.) The Reign of Cnut. King of England, Denmark and Norway, Leicester. London: Leicester University Press, 27-42.

McWhorter, J.H. (2002). What happened to English? Diachronica I9:2, $217-272$.

Minkova, D. (I99I). The History of Final Vowels in English: The Sound of Muting. Berlin: Walter de Gruyter.

Muysken, P. (2000). Bilingual Speech: A Typology of Code-Mixing. Cambridge: Cambridge University Press

Perridon, H. (I999). Review of A. Torp. I998. Nordiske språk i nordisk og germansk perspektiv. Tijdschrift voor Skandinavistiek 20:2, I82-I86.

- (2005). Dialects and written language in Old Nordic II: Old Danish and Old Swedish. O. Bandle, L. Elmevik \& G. Widmark (eds) The Nordic Languages: An International Handbook of the History of the North Germanic Languages (Vol. I). Berlin: Mouton de Gruyter, Iог 8-IO27.

- (2013). The emergence of the s-genitive in Danish. Language Sciences 36, I34-I 46.

Quak, A. (2005). Nordic and North Sea Germanic relations. O. Bandle, L. Elmevik \& G. Widmark (eds) The Nordic Languages: An International Handbook of the History of the North Germanic Languages (Vol. I). Berlin: Mouton de Gruyter, 568-572.

Ringgaard, K. (I986). Flektionssystemets forenkling og middelnedertysk. Arkiv för Nordisk Filologi IOI, I73-I83.

- (I989). Fleksionssystemets forenkling i dansk. Arkiv för Nordisk Filologi 104, I60-165. 
Schrijver, P. (2006). What Britons spoke around 400 A.D. N.J. Higham (ed.) Britons in Anglo-Saxon England. Woolbridge: Boydell, I65-7I.

Thomason, S.G. \& Kaufman, T. (1988). Language Contact, Creolization, and Genetic Linguistics. Berkeley: University of California Press.

Tristram, H.L. (2002). Attrition of inflections in English and Welsh. M. Filppula, J. Klemola \& H. Pitkänen (eds) The Celtic Roots of English. Joensuu: Joensuu University Press, I I I-49.

- (2004). Diglossia in Anglo-Saxon England, or what was spoken Old English like? Studia Anglica Posnaniensia 40, 87-I Iо.

Trudgill, P. (2010). Investigations in Sociohistorical Linguistics. Cambridge: Cambridge University Press.

White, D.L. (2002). Explaining the innovations of Middle English: What, where, and why. M. Filppula, J. Klemola \& H. Pitkänen (eds) The Celtic Roots of English. Joensuu: Joensuu University Press, I 53- I74.

Whitelock, D. (1996). English Historical Documents: Volume I. London: Routledge. 